\title{
Geniposide Isolated from Gardeniae Fructus Induces Time-Dependent Hepatic Injury in Mice
}

\author{
Jing-Wen Zhang ${ }^{1}$, He Feng Chen², Bei-Ming Xu², Jing-Jing Huang ${ }^{2}$ and Wei-Xia Zhang2* \\ ${ }^{1}$ College of Food and Health, Henan Polytechnic, Zhengzhou, China \\ ${ }^{2}$ Department of Pharmacy, Ruijin Hospital, Shanghai Jiaotong University School of Medicine, Shanghai, China
}

*Corresponding author: Wei Xia Zhang, Ph. D of Pharmacology, Department of Pharmacy, Ruijin Hospital, Shanghai Jiaotong

University School of Medicine, Shanghai, China

\section{ARTICLE INFO}

Received: 幽 September 23, 2019

Published: Nectober 11, 2019

Citation: Jing-Wen Zhang, He Feng Chen, Bei-Ming Xu, Jing-Jing Huang, Wei-Xia Zhang. Geniposide Isolated from Gardeniae Fructus Induces Time-Dependent Hepatic Injury in Mice. Biomed J Sci \& Tech Res 21(5)-2019. BJSTR. MS.ID.003676.

Keywords: Geniposide; Mice; Hepatotoxicity; Mechanism; Gardenia Fructus; Administration by Gavage

\section{ABSTRACT}

Background and Objective: Geniposide, a medicine isolated from Gardenia Fructus, can not only treat hepatic disorders, but also can cause liver injury. The current study was conducted to assess the hepatotoxicity of geniposide in mice after sub-acute administration. Materials and Methods: Mice were randomly divided into 4 groups. One group $(\mathrm{n}=10)$ were administered high-dosage geniposide $(1860 \mathrm{mg} / \mathrm{kg}$ daily) by oral administration (p.o.) for 14 consecutive days. The other three groups $(\mathrm{n}=20)$ were administered medium-dosage geniposide $(150 \mathrm{mg} / \mathrm{kg}$ daily), low-dosage geniposide $(50 \mathrm{mg} / \mathrm{kg}$ daily) or saline (control) for 28 consecutive days.On the 14 th day of the experiment, half of each group of mice was sacrificed for testing. Hepatic function markers, as well as the lipid peroxidation and endogenous antioxidants content in the liver were analyzed. The data obtained were determined using one-way analysis of variance (ANOVA) and post hoc Tukey test. Results: Geniposide significantly increased the activities of aspartate transaminase and lactate dehydrogenase in all three experimental groups $(\mathrm{P}<0.01$, vs control group). There was no significant difference in the contents of glutathione, glutathione -S- transferase and superoxide dismutase in the liver tissues of each group. The hepatic level of malondialdehyde in the $1860 \mathrm{mg} /$ $\mathrm{kg}$ group was significantly lower than that in the control group. Conclusion: This study disclosed that geniposide administration to mice could induce a hepatic injury with a time dependent manner rather than a dose dependent manner. Oxidative stress is not the mechanism of geniposide-induced sub-acute hepatotoxicity in mice.

\section{Introduction}

The fruit of Gardenia Fructus (Chinese herbal name is "zhizi") is a traditional Chinese medicinal source which has been widely used for the treatment of various diseases including inflammation, jaundice and hepatic disorders [1]. Geniposide is the main pharmacologically active component of Gardeniae Fructus, and possess anti-inflammatory, antioxidant, anti-carcinogenic, antidepressant, neuroprotective and hepatoprotective activity [2]. A plethora of studies showed that geniposide can alleviate liver injury in mice induced by sepsis [3]. alcohol [4], ischemia/reperfusion [5], Carbon tetrachloride [6], tripterygium glycosides [7] and alphanaphthylisothiocyanate [8]. Nevertheless, animal studies have shown that geniposide itself can cause hepatotoxicity in rats [9]. Due to the widespread use of Gardenia Fructus and its extracts, the purpose of this study is to investigate the sub-acute toxicity of geniposide on the liver of mice and to explore the mechanism of hepatotoxicity, and to provide a basis for its safe use in humans.

\section{Materials and Methods}

\section{Chemicals}

Geniposide with over 99\% purity (by HPLC) was obtained from Vicket Biological Technology Co., Ltd (Sichuan, China). The assay kits of glutathione (GSH), glutathione -S- transferase (GST), superoxide dismutase (SOD), malondialdehyde (MDA) and uridine two phosphate glucuronosyltransferase 1 (UGT1) were supplied by Nanjing Institute of Bioengineering. All other reagents used were of superior quality. 


\section{Animals}

Forty male ICR mice of SPF grade, weighing 18-20 g, were purchased from Shanghai Xipur -Bikai Experimental Animals Co., Ltd. The animals were acclimatized to the laboratory conditions for 10 days prior to the initiation of the experiment. All experiments were carried out in accordance with the Guide to the Care and Use of Experimental Animals (CCAC 1993), and the experimental protocol was approved by the Studies Ethics Committee of Ruijin Hospital affiliated with Shanghai Jiao Tong University School of Medicine.

\section{Experimental Design}

Mice were randomly divided into 4 groups. One group(n=10) were administered high-dosage geniposide (1860 mg/kg daily) by oral administration (p.o.) for 14 consecutive days. The other three groups $(n=20)$ were administered medium-dosage geniposide (150 mg/kg daily), low-dosage geniposide (50 mg/kg daily) or saline (control) for 28 consecutive days. All mice were weighed once a week and the dose was adjusted according to body weight. On the 14th day of the experiment, half of each group of mice was sacrificed for testing. The protocols are self-devised. All mice were anesthetized with sodium phenobarbital by intraperitoneal injection under the condition of fasting overnight. Mice were sacrificed by cervical dislocation. After sacrifice, serum, plasma and liver samples were collected for further analyses. The weights of the liver measured. Part of the liver tissue was immediately transferred into $10 \%$ formalin for histopathological investigation.

\section{Serum Biochemical Assay}

Blood was collected in anticoagulant-free tubes and serum was separated by centrifugation at $3500 \mathrm{~g}$ for $10 \mathrm{~min}$ at $4^{\circ} \mathrm{C}$. Hepatic injury was assessed by measuring serum levels of alanine transaminase (ALT), aspartate transaminase (AST), total bilirubin (TBIL), alkaline phosphatase (ALP) and lactate dehydrogenase (LDH) using an automatic clinical analyzer (7080, HITACHI Ltd., Tokyo,Japan).

\section{Determination of Oxidative Status in the Liver}

A portion of liver was excised, accurately weighed and homogenized in ice-saline to prepare a $10 \%(\mathrm{w} / \mathrm{v})$ tissue homogenate. The homogenate was used for the determination of GSH level, activity of SOD, GST, and UGT1, end product of lipid peroxidation MDA. The total SOD (U in mg protein), UGT1(U in mg protein), GST (U in mg protein), GSH (U in mg protein) and MDA (nmol in mg protein) activity in mice liver were analyzed using assay kit respectively.

\section{Histological Assessment}

Liver slices from individual mice ( $\mathrm{n}=10$ each group) were prepared for histological examination, stained with hematoxylin and eosin(H\&E) and examined by light microscopy (10 x). Histological assessment was blind, and it was examined by pathologists, its morphology was graded as negative (-), mild, moderate, and severe.

\section{Statistical Analyses}

Data were expressed as mean $\pm \mathrm{SD}$. The intergroup variation between various groups was measured by one-way analyses of variance (ANOVA). Results were considered statistically significant if $\mathrm{P}<0.05$. Data were analyzed by SPSS software, version 19(IBM SPSS, Chicago, IL, USA).

\section{Result}

\section{Animal General Observation}

No animal died in all groups, and the activities, eating and hair of the mice were normal in each group.

Compared with the control group, all the experimental groups had a significant decrease in body weight on the 14th day, and the $50 \mathrm{mg} / \mathrm{kg}$ dose group and the $150 \mathrm{mg} / \mathrm{kg}$ dose group also showed a significant decrease at the end of the experiment. The liver coefficients of the two low dose groups were significantly higher than that of the control group at the end of the experiment. However, there was no difference in liver coefficient between groups on the $14^{\text {th }}$ day of the experiment. (Table 1 ).

Table 1: Effect of genipin on liver coefficient in mice $(n=10)$.

\begin{tabular}{|c|c|c|c|}
\hline Group & Days & $\begin{array}{c}\text { Body } \\
\text { Weight }(\mathrm{g})\end{array}$ & $\begin{array}{l}\text { Liver Coefficient } \\
\qquad\left(\times 10^{-2}\right)\end{array}$ \\
\hline \multirow{2}{*}{ Control Group } & $14 d$ & $30.24 \pm 1.93$ & $5.13 \pm 0.11$ \\
\hline & $28 \mathrm{~d}$ & $34.53 \pm 1.11$ & $5.32 \pm 0.35$ \\
\hline \multirow{2}{*}{ Geniposide $(50 \mathrm{mg} / \mathrm{kg})$} & $14 \mathrm{~d}$ & $27.91 \pm 0.87^{* *}$ & $5.50 \pm 0.19$ \\
\hline & $28 \mathrm{~d}$ & $32.44 \pm 1.06^{* *}$ & $6.03 \pm 0.62^{* *}$ \\
\hline \multirow{2}{*}{$\begin{array}{c}\text { Geniposide }(150 \mathrm{mg} / \\
\mathrm{kg})\end{array}$} & $14 d$ & $28.51 \pm 0.96^{*}$ & $5.08 \pm 0.13$ \\
\hline & $28 \mathrm{~d}$ & $31.84 \pm 1.36^{* *}$ & $5.83 \pm 0.68^{*}$ \\
\hline $\begin{array}{c}\text { Geniposide }(1860 \mathrm{mg} / \\
\mathrm{kg})\end{array}$ & $14 \mathrm{~d}$ & $28.06 \pm 1.21^{*}$ & $5.44 \pm 0.38$ \\
\hline
\end{tabular}

Note: Values are mean \pm SD. ${ }^{*} \mathrm{P}<0.05,{ }^{* *} \mathrm{P}<0.01$, Compared with the control group.

\section{Effect of Geniposide on Blood Biochemical Indexes in Mice}

Geniposide significantly increase AST and LDH values at 50, $150 \mathrm{mg} / \mathrm{kg}$ after treatment for 14 days and 28 days, and at $1860 \mathrm{mg} /$ $\mathrm{kg}$ for 14 days $(\mathrm{P}<0.01$, vs control group). Serum ALT obviously increased in both $150 \mathrm{mg} / \mathrm{kg}$ and $1860 \mathrm{mg} / \mathrm{kg}$ groups. Contrary to the other indicators, the TBIL level in $1860 \mathrm{mg} / \mathrm{kg}$ group was significantly lower than that in control group, $50 \mathrm{mg} / \mathrm{kg}$ group and $150 \mathrm{mg} / \mathrm{kg}$ group. There were no obvious differences in ALP between control group and $1860 \mathrm{mg} / \mathrm{kg}$ group, while ALP increased in the groups of geniposide 50 and $100 \mathrm{mg} / \mathrm{kg}(\mathrm{P}<0.01$, vs control group). The data was shown in Table 2. Compared with the data at day 14, there was a significant increase in ALT and AST in the 150 $\mathrm{mg} / \mathrm{kg}$ dose group at the end of the experiment. The levels of ALP and $\mathrm{LDH}$ in the $50 \mathrm{mg} / \mathrm{kg}$ dose group were significantly increased at 28 days compared to 14 days. 
Table 2: Effect of geniposide on blood biochemical indexes in mice $(n=10)$.

\begin{tabular}{|c|c|c|c|c|c|c|}
\hline Group & Days & ALT (IU/L) & AST (IU/L) & TBIL (IU/L) & ALP $($ IU/L) & LDH (IU/L) \\
\hline \multirow{2}{*}{ Control group } & $14 \mathrm{~d}$ & $36.20 \pm 2.34$ & $76.30 \pm 15.58$ & $2.19 \pm 0.02$ & $189.91 \pm 11.86$ & $596.04 \pm 18.26$ \\
\cline { 2 - 7 } & $28 \mathrm{~d}$ & $35.20 \pm 3.12$ & $75.50 \pm 16.24$ & $2.46 \pm 0.37$ & $180.50 \pm 30.85$ & $577.30 \pm 99.29$ \\
\hline $\begin{array}{c}\text { Geniposide (50mg/ } \\
\mathrm{kg} \text { ) }\end{array}$ & $14 \mathrm{~d}$ & $37.27 \pm 2.20$ & $95.60 \pm 14.17^{* *}$ & $2.25 \pm 0.74$ & $229.22 \pm 19.61^{* *}$ & $858.12 \pm 151.26^{* *}$ \\
\cline { 2 - 7 } & $28 \mathrm{~d}$ & $39.50 \pm 4.50$ & $98.70 \pm 13.88^{* *}$ & $2.31 \pm 0.44$ & $251.30 \pm 25.47^{* *+}$ & $971.20 \pm 162.52^{* *}+$ \\
\hline $\begin{array}{c}\text { Genipo- } \\
\text { side (150mg/kg) }\end{array}$ & $14 \mathrm{~d}$ & $41.62 \pm 8.73^{*}$ & $95.14 \pm 17.23^{* *}$ & $2.48 \pm 0.69$ & $221.03 \pm 18.47$ & $901.20 \pm 149.36^{* *}$ \\
\hline \multirow{2}{*}{$\begin{array}{c}\text { Genipo- } \\
\text { side }(1860 \mathrm{mg} / \mathrm{kg})\end{array}$} & $14 \mathrm{~d}$ & $47.80 \pm 9.05^{* *+}$ & $106.60 \pm 19.67^{* *}+$ & $2.58 \pm 0.77$ & $236.00 \pm 22.10^{* *}$ & $945.10 \pm 184.17^{* *}$ \\
\hline
\end{tabular}

Note: Values are mean $\pm \mathrm{SD} .{ }^{*} \mathrm{P}<0.05,{ }^{*} \mathrm{P}<0.01$, Compared with the control group. $+\mathrm{P}<0.05$, compared with the $14^{\text {th }}$ day.

Effect of Geniposide on Biochemical Indexes of Liver Tissue in Mice

Compared with the control group, there was no significant difference in the contents of GSH, GST and SOD in the liver tissues of each geniposide dose group, whether on the 14th day or at the end of experiment.The level of UGT1 was significantly increased in $50 \mathrm{mg} / \mathrm{kg}$ group compared with the control group at the end of experiment. The MDA value of liver tissue in the $1860 \mathrm{mg} / \mathrm{kg}$ geniposide group was significantly lower than that in the control group. The data was shown in Table 3.

Table 3: Effect of genipin on biochemical indexes of liver tissue in mice $(n=10)$.

\begin{tabular}{|c|c|c|c|c|c|c|}
\hline Group & Days & UGT1 $(\mathbf{U} / \mathbf{m g})$ & GSH $(\mathbf{m g} / \mathbf{m g})$ & GST $(\mathbf{U} / \mathbf{m g})$ & MDA $(\mathbf{n m o l} / \mathbf{m g})$ & SOD $(\mathbf{U} / \mathbf{m g})$ \\
\hline \multirow{2}{*}{ Control Group } & $14 \mathrm{~d}$ & $109.16 \pm 23.76$ & $46.65 \pm 25.08$ & $57.96 \pm 23.83$ & $3.49 \pm 0.49$ & $34.79 \pm 10.15$ \\
\cline { 2 - 7 } & $28 \mathrm{~d}$ & $108.39 \pm 47.28$ & $50.99 \pm 17.41$ & $61.04 \pm 25.08$ & $3.67 \pm 1.15$ & $33.90 \pm 9.31$ \\
\hline \multirow{2}{*}{ Geniposide $(50 \mathrm{mg} / \mathrm{kg})$} & $14 \mathrm{~d}$ & $110.24 \pm 17.18$ & $56.77 \pm 8.26$ & $72.16 \pm 17.28$ & $4.45 \pm 2.97$ & $36.09 \pm 3.31$ \\
\cline { 2 - 7 } & $28 \mathrm{~d}$ & $143.54 \pm 41.08^{*}$ & $59.92 \pm 18.89$ & $74.45 \pm 22.18$ & $4.03 \pm 1.17$ & $38.33 \pm 8.11$ \\
\hline \multirow{2}{*}{ Geniposide $(150 \mathrm{mg} / \mathrm{kg})$} & $14 \mathrm{~d}$ & $91.30 \pm 25.04$ & $50.87 \pm 15.43$ & $68.25 \pm 20.19$ & $3.67 \pm 1.05$ & $30.76 \pm 4.58$ \\
\cline { 2 - 8 } & $28 \mathrm{~d}$ & $93.00 \pm 18.59$ & $46.23 \pm 9.72$ & $70.09 \pm 18.59$ & $3.04 \pm 0.60$ & $31.59 \pm 5.87$ \\
\hline Geniposide $(1860 \mathrm{mg} / \mathrm{kg})$ & $14 \mathrm{~d}$ & $121.28 \pm 24.38$ & $55.67 \pm 13.21$ & $74.33 \pm 21.28$ & $2.38 \pm 0.19 *$ & $35.11 \pm 8.51$ \\
\hline
\end{tabular}

Note: Values are mean \pm SD. ${ }^{*} \mathrm{P}<0.05$, Compared with the control group.

\section{Effects of Geniposide on Liver Histology}

Compared with the control group, the pathological changes of liver were observed in different doses, mainly manifested as hepatocyte degeneration and plasma cell infiltration. However, as is shown in Figures 1:A1, A2, B1, B2, C1, C2, D, only 150mg/kg dose group had severe liver cell hydropic degeneration at the end of experiment. In addition, in the middle of the experiment, the incidence of hydropic degeneration and plasma cell infiltration was lower than that at the end of the experiment (Table 4).

Table 4: Effect of geniposide on histopathology of liver in mice $(n=10)$.

\begin{tabular}{|c|c|c|c|c|c|c|c|}
\hline \multirow{2}{*}{ Group } & \multirow{2}{*}{ Days } & \multicolumn{3}{|c|}{ Hydropic Degeneration (n) } & \multicolumn{3}{|c|}{ Plasma Cell Infiltration（n) } \\
\hline & & Mild & Moderate & Severe & Mild & Moderate & Severe \\
\hline \multirow{2}{*}{ Control Group } & $14 \mathrm{~d}$ & - & - & - & - & - & - \\
\hline & $28 \mathrm{~d}$ & - & - & - & - & - & - \\
\hline \multirow{2}{*}{ Geniposide $(50 \mathrm{mg} / \mathrm{kg})$} & $14 \mathrm{~d}$ & 3 & 0 & 0 & 0 & 0 & 0 \\
\hline & $28 \mathrm{~d}$ & 4 & 0 & 0 & 1 & 0 & 0 \\
\hline \multirow{2}{*}{ Geniposide $(150 \mathrm{mg} / \mathrm{kg})$} & $14 \mathrm{~d}$ & 3 & 2 & 0 & 1 & 0 & 0 \\
\hline & $28 \mathrm{~d}$ & 4 & 4 & 2 & 3 & 0 & 0 \\
\hline Geniposide $(1860 \mathrm{mg} / \mathrm{kg})$ & $14 \mathrm{~d}$ & 4 & 5 & 0 & 2 & 0 & 0 \\
\hline
\end{tabular}



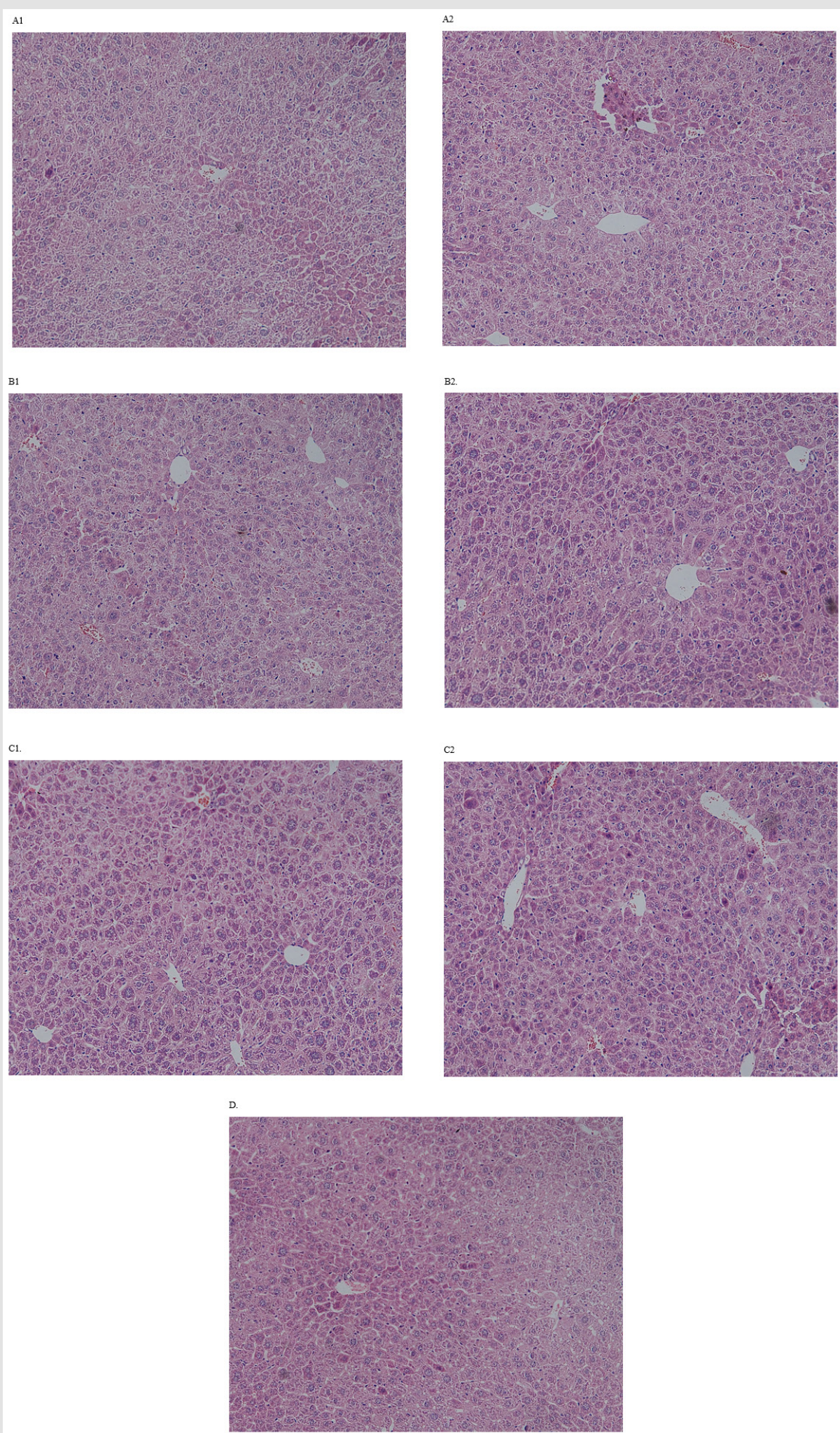

Figure 1: Liver histopathology of mice in each group after the experiment.
a. (A1): Control group on $14^{\text {th }}$ day.
b. (A2): Control group on $28^{\text {th }}$ day.
c. (B1): Group of geniposide $(50 \mathrm{mg} / \mathrm{kg})$ on $14^{\text {th }}$ day.
d. (B2): Group of geniposide $(50 \mathrm{mg} / \mathrm{kg})$ on $28^{\text {th }}$ day.
e. (C1) : Group of geniposide $(150 \mathrm{mg} / \mathrm{kg})$ on $14^{\text {th }}$ day.
f. (C2): Group of geniposide $(150 \mathrm{mg} / \mathrm{kg})$ on $28^{\text {th }}$ day.
g. (D): Group of geniposide $(1860 \mathrm{mg} / \mathrm{kg})$ on $14^{\text {th }}$ day. 


\section{Discussion}

Fructus Gardenia (FG), containing the major active constituent Geniposide, has been widely used in China for the treatment of various diseases including jaundice, diarrheal, and gastroenteritis. The highest daily dose of FG for human is $10 \mathrm{~g}$ recommended in China Pharmacopeia [1]. The minimum content of geniposide in FG is established at $1.8 \%$ but no upper level is defined by the China Pharmacopeia. Nevertheless, the content of geniposide in FG is influenced by many factors, and the highest content is $\sim 6 \%$ which is 3-4 times the minimum standard $[6,10]$. According to the range of content of geniposide in FG (1.8\% to 6\%), the recommended daily dose of geniposide may be equivalent to $180 \mathrm{mg}$ to $600 \mathrm{mg}(3 \mathrm{mg} / \mathrm{kg}$ to $10 \mathrm{mg} / \mathrm{kg}$ for $60 \mathrm{~kg}$ ) in human. According to the dose conversion method between animals and human [11], doses of geniposide $50,150,1860 \mathrm{mg} / \mathrm{kg}$ used in mice in this study could be converted to estimate human equivalent dose $4.05,12.15,150.66 \mathrm{mg} / \mathrm{kg}$ respectively. The doses of $4.05 \mathrm{mg} / \mathrm{kg}$ and $12.15 \mathrm{mg} / \mathrm{kg}$ are within and similar to the daily dose range of geniposide in FG in human mentioned aboved. Thus, potential hepatotoxicity due to geniposide at $50 \mathrm{mg} / \mathrm{kg}$ and $150 \mathrm{mg} / \mathrm{kg}$ in mice may be relevant for humans.

In this study, the toxic effects of geniposide on the liver of mice were found to be related to the exposure time rather than dosage. From the data on the 14th day of the experiment, even at a high dose of $1860 \mathrm{mg} / \mathrm{kg}$, the effect of geniposide on body weight and liver coefficient in mice was not significantly different from the 50 $\mathrm{mg} / \mathrm{kg}$ dose and the $150 \mathrm{mg} / \mathrm{kg}$ dose. As a whole, geniposide can increase the levels of ALT, AST, ALP and LDH in mice. The levels of ALP and LDH in the $50 \mathrm{mg} / \mathrm{kg}$ dose group, and the levels of ALT and AST in the $150 \mathrm{mg} / \mathrm{kg}$ dose group increased over time. However, the degree of elevation of LDH in $1860 \mathrm{mg} / \mathrm{kg}$ dose group is not as high as that in $50 \mathrm{mg} / \mathrm{kg}$ and $150 \mathrm{mg} / \mathrm{kg}$ dose groups. As for ALP, there was even no difference between $1860 \mathrm{mg} / \mathrm{kg}$ group and control group.

In the previous study of the liver toxicity of geniposide in rats, oral administration of geniposide for 3 months did not cause hepatotoxicity at dose levels of 24.3 [12], 60[13], and 72.9 $\mathrm{mg} / \mathrm{kg}$ [12]. In addition, [14] observed that, adminstration of geniposide at dose of $100 \mathrm{mg} / \mathrm{kg}$ administered for 4 weeks, there was no significant toxicity in rats. However, Geniposide could cause liver damage with longer administration duration (26 weeks). Compared with the experiments conducted in rats, very few experiments were carried out in mice. Similar to our study, In Cui's study, Gardenia decoction increased the activities of ALT and AST in mice in a dose dependent manner [15]. As geniposide has been reported not to be lethal when administered orally at a dose of 3 $\mathrm{g} / \mathrm{kg}$ in mice [16], a dose of $1860 \mathrm{mg} / \mathrm{kg}$ was adiministered in our study to verify whether hepatotoxicity is dose dependent. Due to the short duration of administration, the toxic effect of 1860mg/ $\mathrm{kg}$ dose group on liver is not more significant than that of $150 \mathrm{mg} /$ $\mathrm{kg}$ dose group.

In traditional chinese medicine, Yinchenhao decoction, a well-known traditional Chinese herbal formula, has been widely used for more than a thousand years to treat jaundice and liver disorders [17]. In Japan, it is also called Inchin-ko-to or TJ-135, which is known to inhibit hepatocyte apoptosis as well as promote the secretion and excretion of bile [4]. In Tian's study, geniposide significantly decrease TBIL values in both sexes at 50, $100 \mathrm{mg} /$ $\mathrm{kg}$ after treatment for 4 weeks and 13 weeks and at all three dose levels after administration for 26 weeks $(\mathrm{P}<0.01$, vs control group) in rats. In this study, it was found that the level of TBIL in $1860 \mathrm{mg} / \mathrm{kg}$ group decreased significantly after continuous gavage for 2 weeks, but in the other two groups $(50 \mathrm{mg} / \mathrm{kg}$ and $150 \mathrm{mg} / \mathrm{kg}$ ), after 28 days of administration, there was no difference in TBIL level comparing with the control group. On the contrary, in the study by Sato et al.[13], after 3-month ingestion of gardenia yellow powder containing geniposide 5.72, 18.9 and $56.3 \mathrm{mg} / \mathrm{kg} /$ day in the gardenia yellow A, B and C groups, respectively, the level of total bilirubin in gardenia yellow $\mathrm{C}$ group in rats is significantly higher comparing with control group. Genipin, a metabolite of geniposide, has been reported can stimulate the insertion of Mrp2 into the bile canalicular membrane, and causes choleresis by increasing the biliary excretion of glutathione, which has been considered to be a substrate of Mrp2 stimulate [18]. As for the condition of which geniposide can affect the level of TBIL, further studies are needed.

The mechanism of geniposide induced hepatotoxicity has not been elucidated, though oxidative stress was postulated $[12,19]$. However, in this study, there was no corresponding change in the indexes of lipid peroxidation(GSH, SOD)in those mice with elevated aminotransferase, and the level of MDA in $1860 \mathrm{mg} / \mathrm{kg}$ group after two weeks was significantly reduced, this is different from the acute toxicity study of genipin in rats (geniposide $819.2 \mathrm{mg} / \mathrm{kg}$ per gavage for 48h) [12], which has an increased level of MDA. Therefore, The role of free radicals in geniposide induced hepatotoxicity is uncertain. GST, as a phase II metabolic enzyme, through catalyzing the binding of reduced glutathione to a series of electronophilic compounds, can detoxify and protect the electronophile carcinogens and exogenous poisons from entering human body. Geniposide can activate GST by inducing the expression of M1 and M2 subunits of GST $[20,21]$. However, this study didn't find significant difference in the level of GSH between four groups.

In conclusion, sub-acute administration of geniposide at $50 \mathrm{mg} / \mathrm{kg}$ and $150 \mathrm{mg} / \mathrm{kg}$, or $1860 \mathrm{mg} / \mathrm{kg}$ can lead to liver injury in mice. Hepatotoxicity manifested in the level of ALT, AST and LDH. However, the TBIL level in $1860 \mathrm{mg} / \mathrm{kg}$ group was significantly lower than that in control group, $50 \mathrm{mg} / \mathrm{kg}$ group and $150 \mathrm{mg} / \mathrm{kg}$ group. As the level of GSH and SOD did not change significantly in mice with injured liver, oxidative stress is not likely to be involved in geniposide-induced liver damage. The mechanism of hepatotoxicity induced by geniposide in mice deserves further investigation.

\section{Acknowledgement}

We thank Ms.Yan Guo for helps in histological assessment. This work was supported by Shanghai Science and Technology Projects under Grant 16DZ1911103. 


\section{Disclosure statement}

The authors declare that there are no potential conflicts of interest.

\section{References}

1. (2015) National pharmacopoeia committee. Pharmacopoeia of People's Republic of China. Part 1. 248 (Beijing).

2. Phatak, Rohan (2015) Phytochemistry, Pharmacological Activities and Intellectual Property Landscape of Gardenia jasminoides Ellis: A Review. Pharmacognosy Journal 7(5): 254-265.

3. Cho HI, Kim SJ, Choi JW, Lee SM (2016) Genipin alleviates sepsis-induced liver injury by restoring autophagy. British Journal of Pharmacology 173: 980-991.

4. Zhang T, Zhang A, Qiu S, Sun H, Han Y, et al. (2016) High-throughput metabolomics approach reveals new mechanistic insights for drug response of phenotypes of geniposide towards alcohol-induced liver injury by using liquid chromatography coupled to high resolution mass spectrometry. Molecular Bio Systems 13: 73-82.

5. Kim J, Kim HY, Lee SM (2013) Protective Effects of Geniposide and Genipin against Hepatic Ischemia/Reperfusion Injury in Mice. Biomolecules \& Therapeutics (Seoul) 21(2): 132-137.

6. Chen Y, Zhang H, Li YX, Cai L, Huang J, et al. (2010) Crocin and geniposide profiles and radical scavenging activity of gardenia fruits (Gardenia jasminoides Ellis) from different cultivars and at the various stages of maturation. Fitoterapia 81(4): 269-273.

7. Wang J, Miao M, Qu L, Cui Y, Zhang Y (2016) Protective effects of geniposide against Tripterygium glycosides (TG)-induced liver injury and its mechanisms. Journal of the toxicological sciences 41(1): 165173.

8. Tian J, Yi Y, Zhao Y, Li C, Zhang Y, et al. (2016) Geniposide Inhibits Alpha-Naphthyl isothiocyanate-Induced Intrahepatic Cholestasis: The Downregulation of STAT3 and NF [Formula: see text] B Signaling Plays an Important Role. The American journal of Chinese medicine 44(4): 721-736.

9. Yamano T, Tsujimoto Y, Noda T, Shimizu M, Ohmori M, et al. (1990) Hepatotoxicity of geniposide in rats. Food and chemical toxicology 28(7): 515-519.

10. Zhao SJ, Yang Y, Liang DX, Liang DZ, Zhang C (1994) Quantitative analysis of geniposide in fructus Gardeniae and its different processed products. Zhongguo Zhong Yao Za Zhi 19(10): 601-638.

ISSN: 2574-1241

DOI: 10.26717/BJSTR.2019.21.003676

Wei-Xia Zhang. Biomed J Sci \& Tech Res

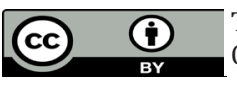

This work is licensed under Creative Commons Attribution 4.0 License

Submission Link: https://biomedres.us/submit-manuscript.php
11. Nair AB, Jacob S (2016) A simple practice guide for dose conversion between animals and human. Journal of basic and clinical pharmacy $7(2): 27-31$.

12. Ding Y, Zhang T, Tao JS, Zhang LY, Shi JR, et al. (2013) Potential hepatotoxicity of geniposide, the major iridoid glycoside in dried ripe fruits of Gardenia jasminoides (Zhi-zi). Natural product research 27(10): 929-933.

13. Sato S, Kitamura H, Chino M, Takei Y, Hiruma M, et al. (2007) A 13week oral dose subchronic toxicity study of gardenia yellow containing geniposide in rats. Food and chemical toxicology 45(8): 1537-1544.

14. Tian J, Yi Y, Zhao Y, Li C, Zhang Y, et al. (2018) Oral chronic toxicity study of geniposide in rats. Journal of ethnopharmacology 213: 166-175.

15. Yizhe Cui, Rui Sun, Qiuju Wang, Mengzhu Wang (2017) Hepatotoxicity induced by intragastrically administrated with Gardenia decoction in mice. Natural product research 31(23): 2824-2827.

16. Harada M, Tenmyo N, Aburada M, Endo T (1974) Phagmacological studies of gardeniae fructus. I. Effect of geniposide and genipin on the biliary excretion, the gastric juice secretion, and the gastric contraction, and other pharmacological actions (author's transl). Yakugaku Zasshi 94(2): 157-162.

17. Aihua Zhang, Hui Sun, Shi Qiu, Xijun Wang (2013) Advancing drug discovery and development from active constituents of yinchenhao tang, a famous traditional chinese medicine formula. Evidence-based complementary and alternative medicine.

18. Mikami M, Takikawa H (2008) Effect of genipin on the biliary excretion of cholephilic compounds in rats. Hepatology research 38(6): 614-621.

19. Yang HJ, Fu MH, Wu ZL, Liang RX, Huang LQ, et al. (2006) Experimental studies on hepatotoxicity of rats induced by Fructus Gardeniae. Zhongguo Zhong Yao Za Zhi 31(13): 1091-1093.

20. Kuo WH, Chou FP, Young SC, Chang YC, Wang CJ (2005) Geniposide activates GSH S-transferase by the induction of GST M1 and GST M2 subunits involving the transcription and phosphorylation of MEK-1 signaling in rat hepatocytes. Toxicology and applied pharmacology 208(2): 155-162.

21. PingChen, Yang Chen,Yarong Wang, Shining Cai, Liang Deng, et al. (2016) Comparative Evaluation of Hepatoprotective Activities of Geniposide, Crocins and Crocetin by CCl4-Induced liver Injury in Mice. Biomolecules \& Therapeutics (Seoul) 24(2): 156-162.

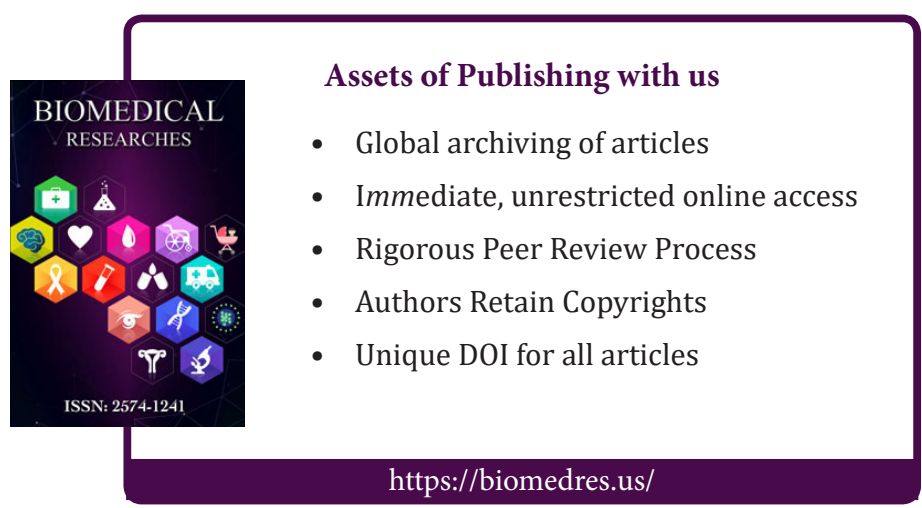

